Nikola Petrašinović

Research Associate University of Belgrade

Faculty of Mechanical Engineering

Danilo Petrašinović

Teaching Assistan University of Belgrade

Faculty of Mechanical Engineering

Boško Rašuo

Full Profesor

University of Belgrade

Faculty of Mechanical Engineering

Dragan Milković

Teaching Assistant University of Belgrade

Faculty of Mechanical Engineering

\title{
Aircraft Duraluminum Wing Spar Fatigue Testing
}

Experimental fatigue crack growth analysis of the aircraft structural component subjected to different cycling loading has been presented. The purpose of the experimental test was to evaluates the fatigue behavior of the real aircraft spar, made in aluminum 2024-T3. In-house laboratory fatigue test installation is described in the paper. The spar-test specimen has been manufactured specifically for the cycling damage testing. Test results were obtained with most modern equipment for data acquisition. Applied loads and obtained spar fatigue results are described in detail. Conclusions have been made with reference to the previous work on the duraluminum spar fatigue testing. As it is presented in the previous work with advanced numerical methods for fatigue analysis, in this paper is given an opinion on the same. At the end, possible directions of the further experimental spar fatigue testing is given and shows us that it makes sense to make the comparison beetwen real and numerical results only in situations where cracks behave similarly and the numbers of required cycles are about the same.

Keywords: wing spar, fatigue testing, crack, alluminum alloy 2024-T3, test installation.

\section{INTRODUCTION}

Today, aircraft engineers are making great efforts to analyze and predict fatigue crack growth in aircraft structures. It is widely accepted that the small crack propagation takes up the most of the fatigue life, especially in materials (like aluminum alloys) used for primary aircraft components such as the wing spar [1]. Fatigue failure of wing spar may lead to catastrophic consequences, so the analysis of fatigue crack growth in spar under cyclic loading conditions is of the greatest importance.

Due to the lack of the general methods for stress analyses in the plasticity range of statically indeterminate structures of any type, reliable intensity of fracture load can be determined only experimentally [1].

The objective of this examination is the testing of the complete aircraft structure, complete assemblies such as complete wing, fuselage, landing gear, tail surfaces or basic elements, etc [2].

In dynamic aero elastic problems, we are concerned with the oscillatory motion of various structural parts of aircraft, and particularly interested in the conditions under which these oscillatory modes tend to result structural failure.

On the basis of detailed theoretical and experimental study of aero elastic problems, it was found that the stiffness of the structure is of primary importance for the aero elastic phenomena [3], [4].

Received: October 2015, Accepted: December 2016

Correspondence to: M. Sc. Nikola Petrašinović

Faculty of Mechanical Engineering,

Kraljice Marije 16, 11120 Belgrade 35, Serbia

E-mail: npetrasinovic@mas.bg.ac.rs

doi:10.5937/fmet1704531P

(c) Faculty of Mechanical Engineering, Belgrade. All rights reserved
This paper presents full scale fatigue testing of the aircraft metal wing supporting element. The element was subjected to the symmetrical cyclic loading until the point of loss of security of wing structural supporting element [5], [6]. During the experiment, fatigue characteristics were measured. After processing, obtained results were compared with advanced numerical method [7]. As a result we found very good agreement between the results.

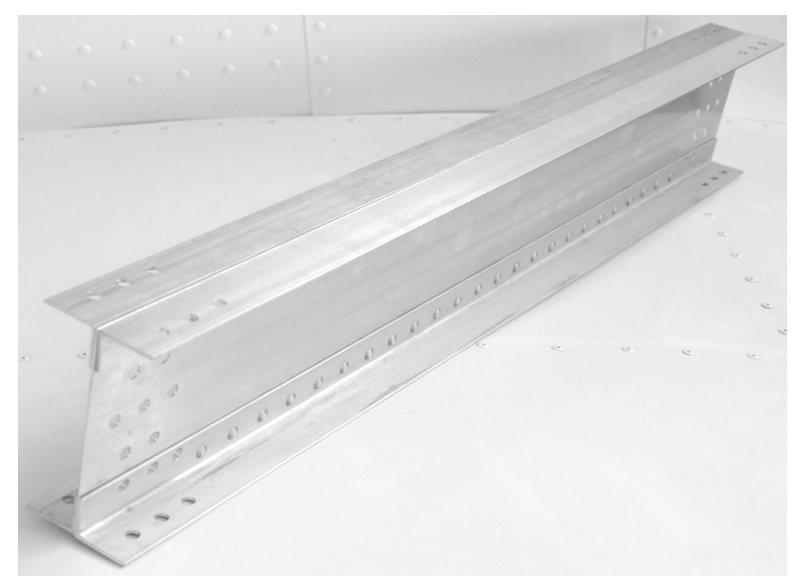

Figure 1. Aluminum spar

\section{TEST SPECIMENS}

The purpose of the experimental test was to evaluate the fatigue behavior of the real aircraft spar, made in aluminum 2024-T3 [2], under cycling loading. Alloy 2024 products are used in fuselage and wing tension members, shear webs and ribs and structural areas where high stiffness, fatigue performance and good strength characteristics are required. The table 1 shows 
the chemical composition of the material. The test specimen is full scale and a geometrical representative of a light aircraft spar, Fig. 1.

Table 1. Chemical composition of the material

\begin{tabular}{|c|c|}
\hline Element & Chemical composition (\%) \\
\hline $\mathrm{Al}$ & $90.7-94.7$ \\
\hline $\mathrm{Cr}$ & $\max 0.1$ \\
\hline $\mathrm{Cu}$ & $3.8-4.9$ \\
\hline $\mathrm{Fe}$ & $\max 0.5$ \\
\hline $\mathrm{Mg}$ & $1.2-1.8$ \\
\hline $\mathrm{Mn}$ & $0.3-0.9$ \\
\hline $\mathrm{Si}$ & $\max 0.5$ \\
\hline $\mathrm{Ti}$ & $\max 0.15$ \\
\hline $\mathrm{Zn}$ & $\max 0.25$ \\
\hline $\mathrm{Rest}$ & $\max 0.15$ \\
\hline
\end{tabular}

The test specimen, elementary part of the wing main spar, with its common and basic dimensions (Fig. 2) has been manufactured specially for the cycling damage testing.

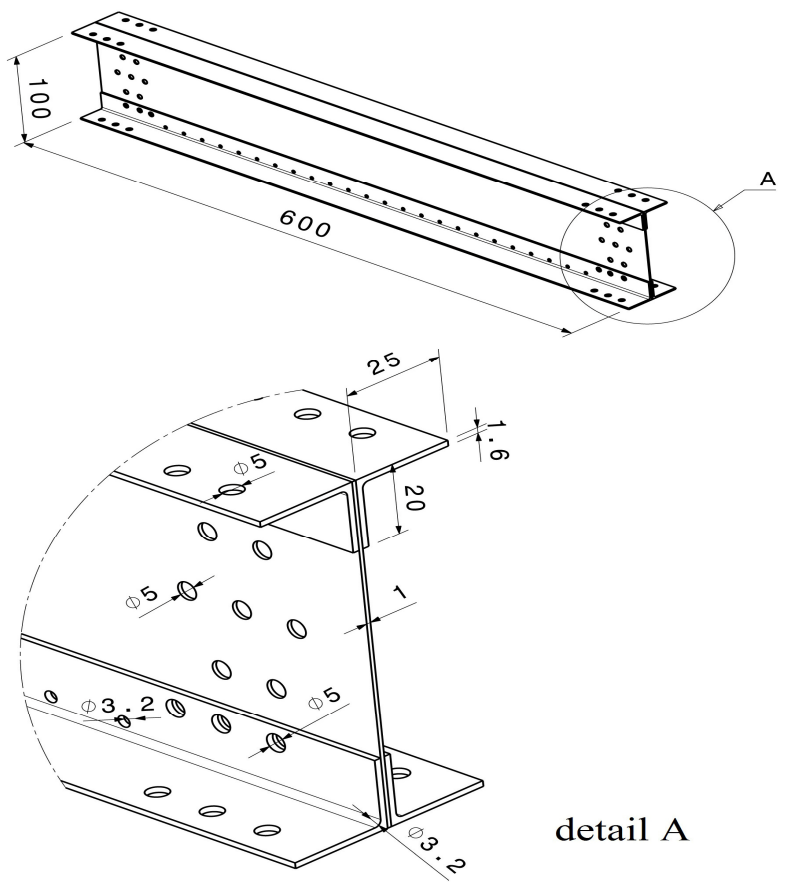

Figure 2. Spar model

Spar caps and the spar wall were conected with rivets also made of aluminum alloy 2024-T3 [2]. To ensure maximum homogeneity of the spar structure, rivets were placed at the distance of $25 \mathrm{~mm}$, detail A (Fig. 2).

\section{TEST INSTALATION}

As it is shown in the Figure 3 one side of the spar was clamped with the test installation frame. On the other side, the spar was connected with an adjustable drawbar that was also connected with an adjustable eccentric disc.

The main advantages of the adjustable eccentric disc are 4 independent clamping jaws, which enable displacement in different directions. To prevent undesired torsion, and tensure only bending of the spar end, the spar was also attached with 4-bearing slider [8].
Test installation used in the experiment consists of two basic sections:

- Test rig,

- Measuring system.

\subsection{TEST RIG}

The test rig consists of the following components [8-9]:

- Robust cast supporting frame connected to the laboratory floor. The reason for using cast iron frame is big mass and rigidity, which disable the cause of possible vibration during testing.

- Robust dovetail slider cantilever. It enables us to set different console length for different test speciemens.

- Clamp with a large number of holes for connecting different test specimens.

- Linear guide connected to dovetail slider cantilever enables transversal movement.

- $4 \mathrm{~kW}$ electromotor, with the rotation speed of $750 \mathrm{rpm}$, also connected to the laboratory floor.

- Adjustable eccentric disc with 4 independent clamping jaws, which enables setting of the amplitudes and directions of the applied displacement.

- Rigid adjustable drawbar that enables fine displacement adjustments.

- 4-bearing slider which ensures only bending of the spar end (Item 1 in Fig. 5).

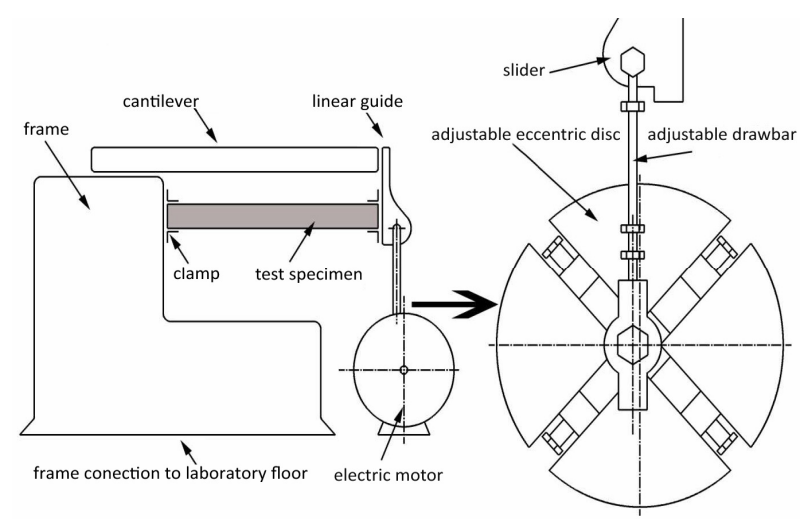

Figure 3. Test rig scheme

\subsection{MEASURING SYSTEM}

Measuring equipment used in the experiment consists of the following [1]:

- Hottinger Baldwin Messtechnik U3 $50 \mathrm{kN}$ force transducer (Item 1 in Fig. 4), directly connected to the adjustable drawbar in order to obtain the best feedback about the applied force.

- ELAP PMS2S $150 \mathrm{~mm}$ linear displacement transducer (Item 2 in Fig. 4) was used for measuring deflection in relation to a central point.

- Hottinger Baldwin Messtechnik B12 accelerometer which was used for measuring acceleration of the slider (Item 2 in Fig. 5) 
- Aluminum strain gauges HBM 1-LY13$10 / 120$ types were used for stress measuring in the spar clamp zone at four measuring points. Each strain gauge (Fig. 6) was also connected to a dummy strain gauge into one half of the Wheatstone bridge, and then to the acquisition system.

- Data recording and some simple analyses were performed using HBM SPIDER8 acquisition system and Catman Express software package.

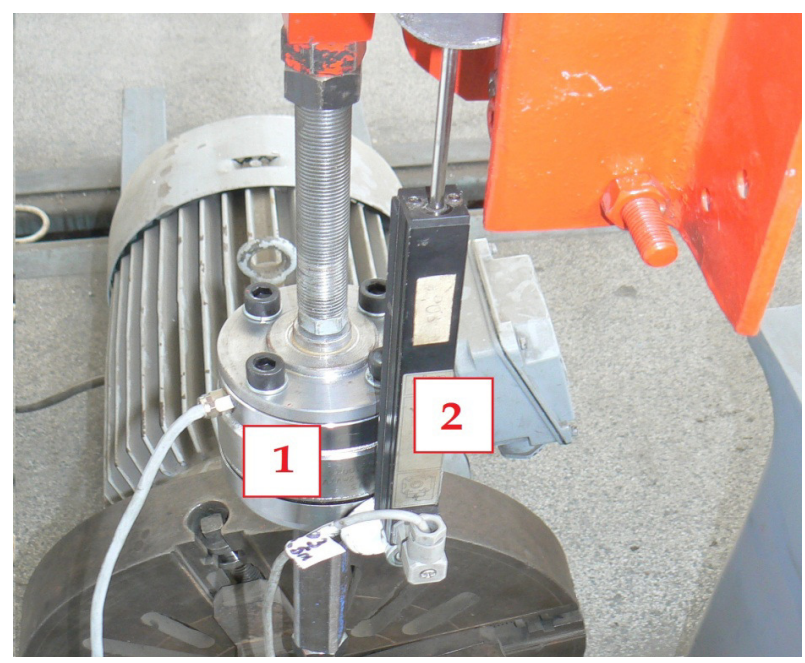

Figure 4. Force and displacement transducers

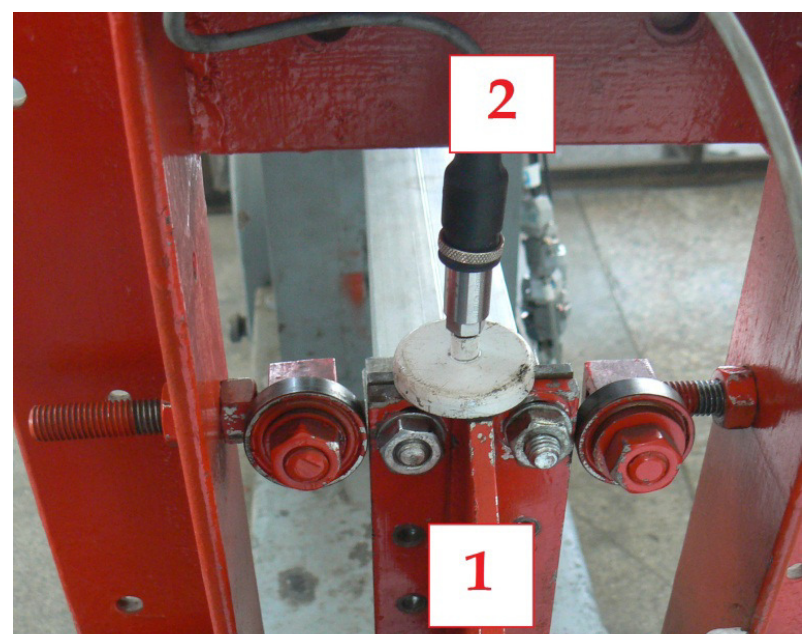

Figure 5. 4-bearing slider with mounted accelerometer

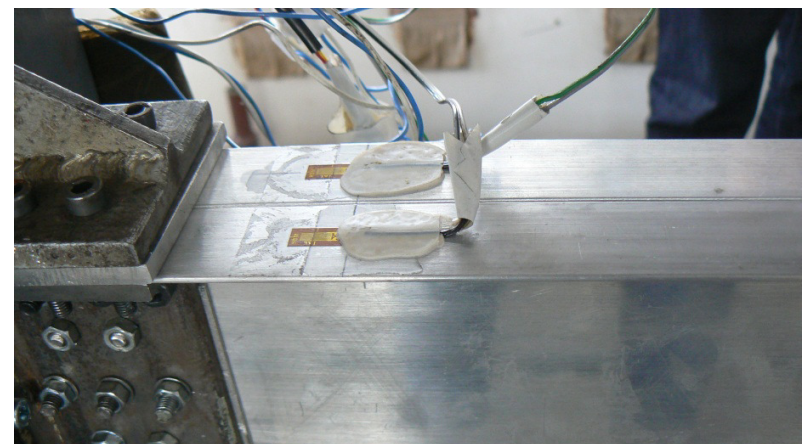

Figure 6. Strain gages

Strain gages were applied at four measuring points, which are expected to be critical for the analysis [10]. They were placed on the both spar caps $20 \mathrm{~mm}$ from the clamp zone. At the numerical model can be seen that this zone, is the zone with the highest normal stresses, Fig. 7.

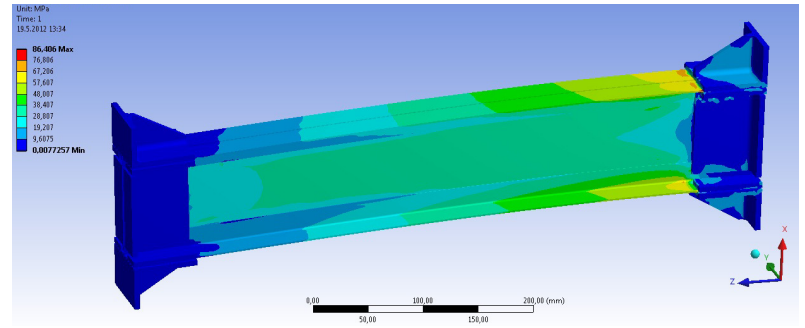

Figure 7. Normal stresses distribution

\section{FATIGUE TEST RESULTS}

The wing spar fatigue test was carried out in the Laboratory for static and dynamic analysis of aircraft structures at the Faculty of Mechanical Engineering, University of Belgrade.

In the first phase of the experiment, static values of the force and displacement at the end of the test spar were measured (Fig. 8 and 9).

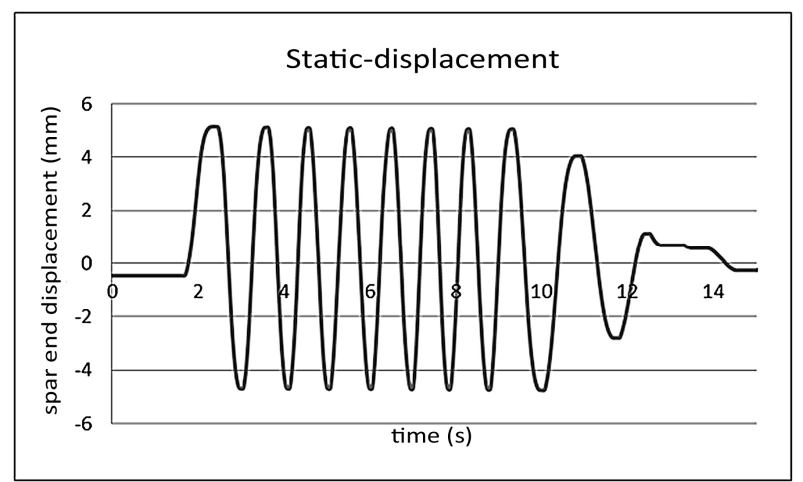

Figure 8. Static- displacement

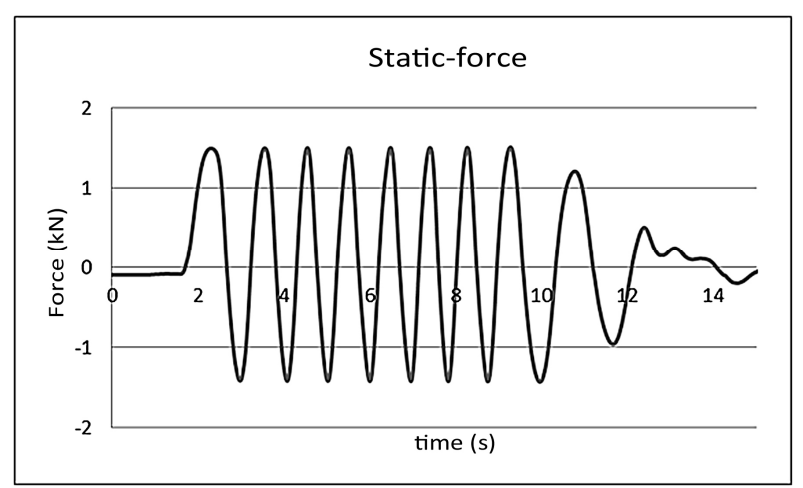

Figure 9. Static-force

From these two diagrams it can be seen that the narrow band sequence load has been added. The total amplitude of the displacement was $9 \mathrm{~mm}$, which is significantly higher value compared to previous tests. For this value of the displacement forces ranged from 1.5 to $+1.5 \mathrm{kN}$.

After the static measurement was carried out, dynamic force was measured at the frequency of 12.5 Hz. Fig. 10 shows the applied loads, with small insignificant changes from the static image.

On the next 4 diagrams is presented whole range of the loads. Different shapes of dilatation vs. time diagrams are due to existence of the imperfections in the 
material, such as residual stresses induced by the production process.

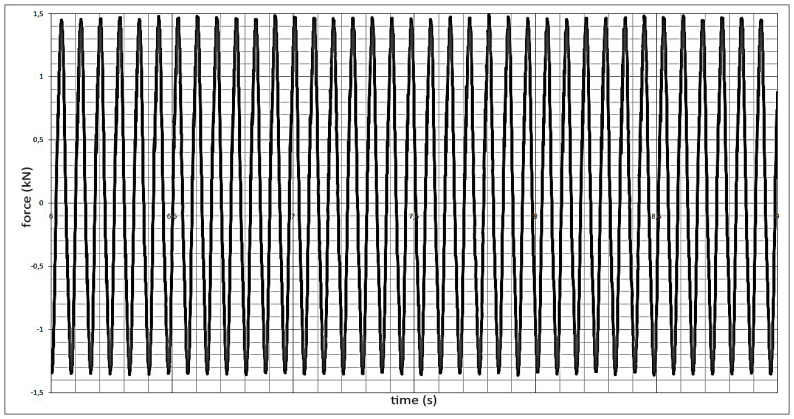

Figure 10. Force vs. time - dynamics

At the upper right spar cap measuring zone, shown in Fig. 11., micro crack first appeared which can be seen on the dilatation vs. time diagram, in the upper part of the right spar cape zone after 3500 seconds (43 750 cycles). After cracking, it spread for the next 6500 (81250 cycles) seconds until the termination of the experiment, when it was obvious that there exists a fracture. Based on the number of cycles until fracture we can conclude that is in the elastic plastic range and low cyclical fatigue. Also, the diagram shows that the micro dilatation at the lower spar cap zone kept constant shape which indicates that right spar cap retained the ability to carry loads.

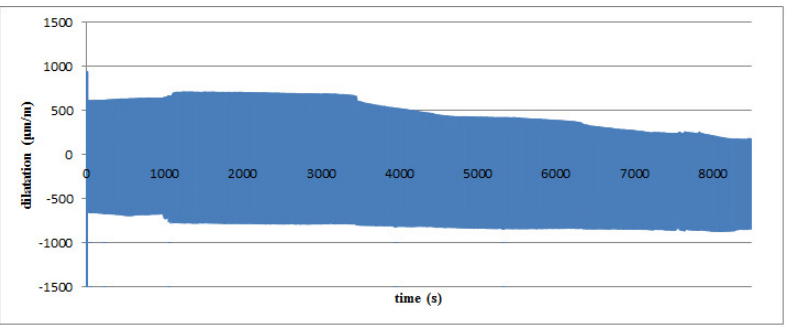

Figure 11. Dilatation vs. time measured at the upper right spar cap zone

Fig. 12. shows crack at the right upper spar cap zone.

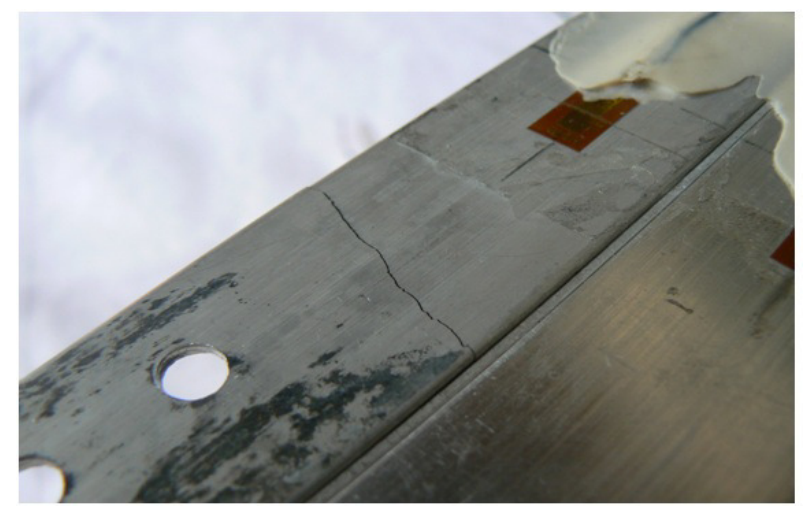

Figure 12. The crack at the upper right spar cap zone

At the lower left spar cap measuring zone, shown in Fig. 13., micro crack also appeared in the upper part of the left spar cap zone after 5000 seconds (62 500 cycles). Brittle fracture of materials can be observed after 6800 seconds (85 000 cycles). Cause of micro dilatation increase in the lower part zone is load transfer on the spar wall.

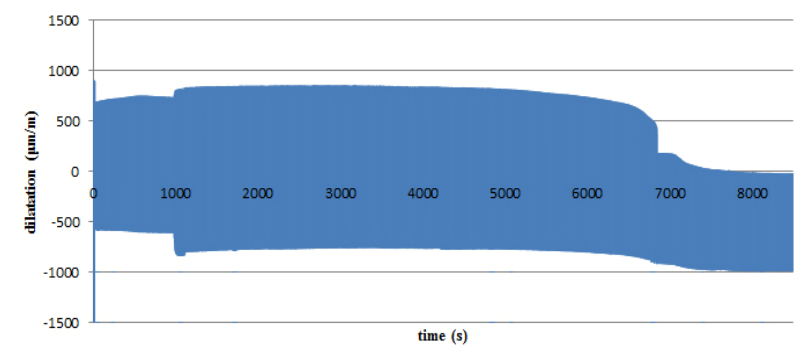

Figure 13. Dilatation vs. time measured at the lower left spar cap zone

Fig. 14. shows crack at the left lower spar cap zone.

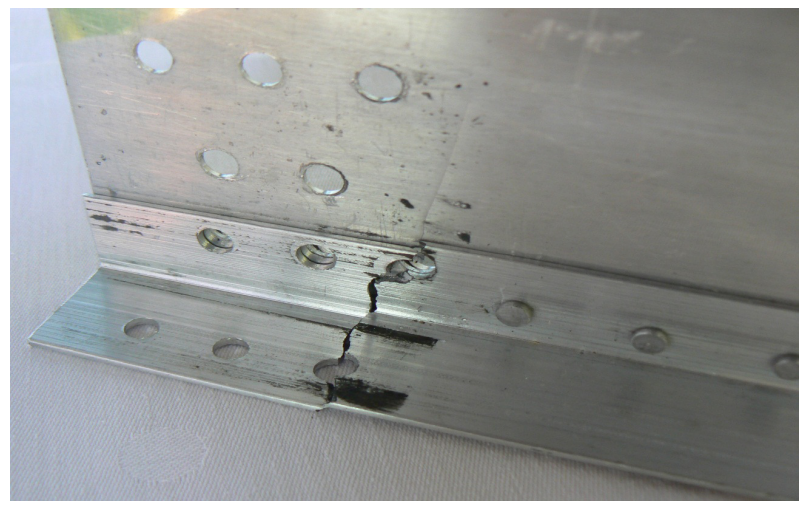

Figure 14. The crack at the left lower spar cap zone

At the lower right spar cap measuring zone shown in Fig. 15. micro crack appeared in the lower part of the left spar cap zone after 3000 seconds (37 500 cycles). At the upper zone there has been a slight increase of the micro dilatation, also due to the load transfer trough the spar wall.

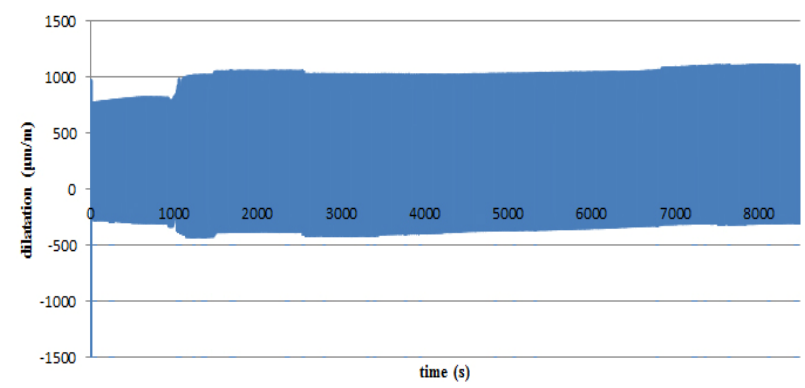

Figure 15. Dilatation vs. time measured at the right lower spar cap zone

Fig. 16. shows crack at the right lower spar cap zone.

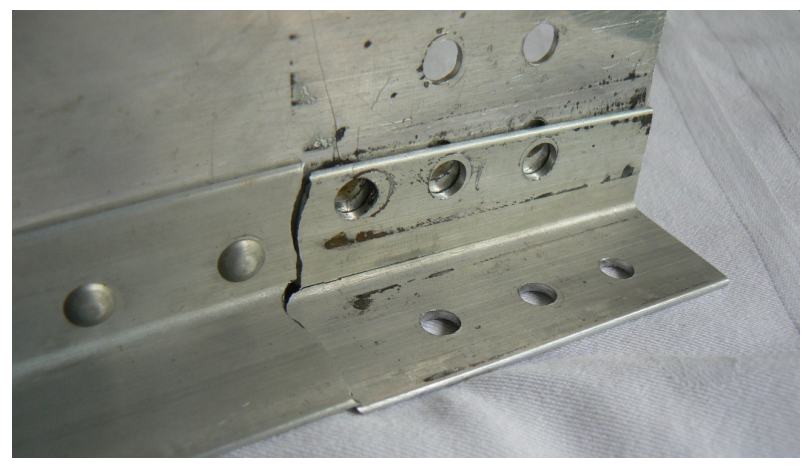

Figure 16. The crack at the right lower spar cap zone

At the upper left spar cap measuring zone micro crack did not appeared until termination of the experiment. 


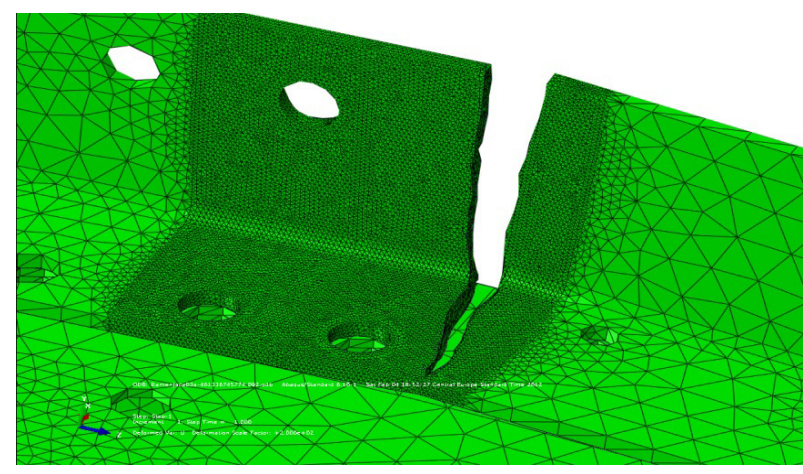

Figure 17. Virtual crack path

The experiment was terminated after 90000 seconds, when it was obvious that there were a large number of fatigue cracks. Although the experiment was terminated before the final fracture of the entire cross section, the time elapsed until the time which is very close to the time of spar fatigue life.

After the experiment termination, we have seen that the crack that could not be seen during experiment started to spread to spar wall. Wall crack is shown in the Fig. 18.

In previous spar fatigue works this type of crack propagation never appeared. However these results coincided with the numerical crack propagation model [10], [11], [12] developed in the previous spar fatigue work, Fig. 17.

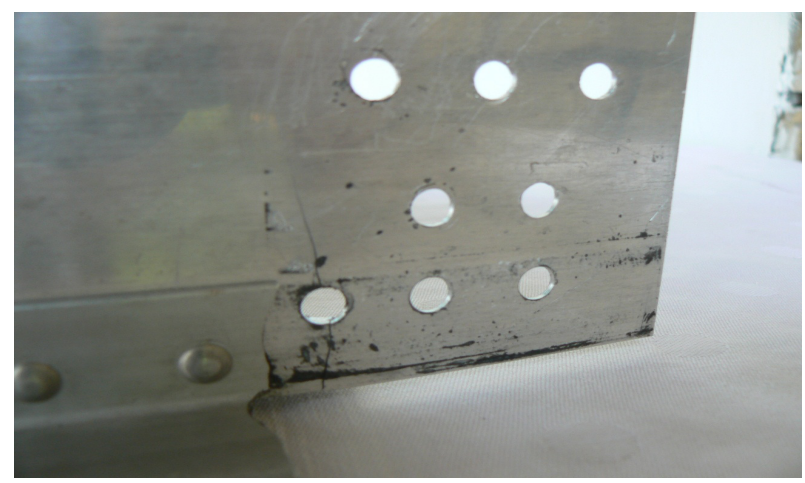

Figure 18. Wall crack path

The differences between real and virtual crack propagation, as well as the points between which they extended, lead us to conclude that it makes sense to make the comparison only in situations where cracks behave similarly and the numbers of required cycles are about the same.

Entering the zone between the vertical and horizontal spar wall there was a small difference in the "behavior" of the virtual and the real crack [13], which is explained by assuming the existence of residual tensile stresses and/or micro-damage of materials (Fig. 6 and 17).

Also, we can conclude that crack propagation $[7,8$, 14] in the areas of holes for rivets, is result of poor drilling process, which is a common theme in the field of fatigue of aircraft structures.

\section{CONCLUSIONS}

In the future it is necessary to perform more experiments on the spar fatigue life, with different number of cycles and variety of different loads. The results of these tests provide an even better basis for making conclusions on wing spar fatigue life.

Further analyses and comparison between the results of the numerical methods and the experimental results will support development of the modern numerical methods as a power tool for fatigue crack growth prediction [9].

The presented experimental results and the behavior of the wing spar under cyclic loading were more or less expected, considering long-term of experience in dealing with aircraft and other structures fatigue life.

\section{REFERENCES}

[1] Petrašinović, D., Aircraft Metal Wing Structural Parts Fatigue Life Analasys, Ph.D. Thesis, University of Belgrade, Faculty of Mechanical Engineering, Belgrade, 2012.

[2] Rašuo, B.: Aircraft production technology, Faculty of Mechanical Engineering, Belgrade, 1995, (in Serbian).

[3] Les Pook, Metal Fatigue, Springer, 2007.

[4] Arthur J. McEvily, Metal Failures: Mechanisms, Analysis, Prevention, Wiley-Interscience, 2001.

[5] Lamas, J., Edwards, M.: P-3C Service Life Assessment Program - FullScale Fatigue Test. Presented at the 22nd Symposium of International Committee on Aeronautical Fatigue, Lucerne, Switzerland; May 2003.

[6] Bo, L., Yifu, S., Weiye, H.: Casting defects induced fatigue damage in aircraft frames of ZL205A aluminum alloy - A failure analysis, Materials and Design, Vol. 32, pp. 2570-2582, 2011.

[7] Grbovic A. et al. Simulation of crack propagation in titanium mini dental implants (MDI). FME Trans 2011; 39 (4): 165-70.

[8] Petrašinović, D., Rašuo, B. and Petrašinović, N.: Extended finite element method (xfem) applied to aircraft duralumin spar fatigue life estimation, Tehnički vjesnik/Technical Gazette, Vol. 19, No. 3, pp. 557-562, 2012. ISSN 1330-3651.

[9] Grbovic, A., Rasuo, B, FEM based fatigue crack growth predictions for spar of light aircraft under variable amplitude loading, Engineering Failure Analysis, Volume 26, December 2012, Pages 5-64.

[10] Infante, V. and Silva, J.M.: Case studies of computational simulations of fatigue crack propagation using finite elements analysis tools, Engineering Failure Analysis, Volume 18, Issue 2, Pages 616-24, March 2011.

[11] Sangid, M. et al., et al.: High resolution analysis of opening and sliding in fatigue crack growth, International Journal of Fatigue, vol. 37, p. 134-145, 2012.

[12] Gu, Y. T. and Zhang, L. C.: Coupling of the meshfree and finite element methods for determination of the crack tip fields, Engineering Fracture Mechanics. vol. 75, p. 986-1004, 2008.

[13] Sabsabi, M., Giner, E. and Fuenmayor, F. J., Experimental fatigue testing of a fretting complete 
contact and numerical life correlation using $\mathrm{X}$ FEM, International Journal of Fatigue. vol. 33, p. 811-822, 2011.

[14] Sukumar, N., Chopp, D. L. and Moran, B.: Extended finite element method and fast marching method for three-dimensional fatigue crack propagation, Engineering Fracture Mechanics. vol. 70, p. 29-48, 2003.

\section{ЕКСПЕРИМЕНТАЛНО ОДРЕБИВАЊЕ ЗАМОРНОГХ ВЕКА ДУРАЛУМИНИЈУМСКЕ РАМЕЊАЧЕ КРИЛА}

Н. Петрашиновић, Д. Петрашиновић, Б. Рашуо, Д. Милковић

У раду је приказана експериментална анализа ширења заморне прслине у структуралном делу ваздухопловне конструкције под цикличним оптере-ћењем. Циљ експерименталне анализе је да се одре-ди стварни заморни век рамењаче направљене од алуминијума 2024-Т3. Испитна инсталација, за испитивање заморних карактеристика ваздухопло-вних конструкција, сопствене израде приказана је у потпуности. Испитни узорак коришћен у раду направљен је искључиво за испитивање на замор. Резултати заморног испитивања прикупљени су најсавременијом опремом за аквизицију података. Примењена оптерећења, као и прикупљени резул-тати су детаљно изложени у тексту. На основу претходно спроведених истраживања, донети су за-кључци о добијеним резултатима експерименталне анализе као и упоредна анализа експерименталне и савремене нумеричке методе. На крају рада дате су смернице у ком правцу би требала да иду даља експериментална истраживања, која нам показују да има смисла вршити поређење између реалних и нумеричких резултата само у ситуацији где су број потребних циклуса и понашање заморних прслина исти. 